Információközvetítés és közösségépítés - multifunkciós könyvtári hálózatok.

Szerk. Kiszl Péter, Németh Katalin. Budapest, ELTE BTK

Könyvtár- és Információtudományi Intézet. 2020. 247-261.

\title{
A KÖNYVTÁRAK HELYZETE OLASZORSZÁGBAN TORINÓ KÖNYVTÁRI HÁLÓZATA
}

\author{
KÖMÜVES RENÁTA
}

\section{TARTALMI ÖSSZEFOGLALÓ}

Olaszországban könyvtárak százai őrzik a múlt írásos emlékeit, azonban az általános olasz könyvtári rendszert viszonylagos szegénység és elmaradottság jellemzi. Az ország északi és déli része között mély szakadék húzódik, mely kihat a könyvtárügyre is. Észak-Olaszország könyvtári ellátottsága gazdag, itt található az ország könyvtárainak fele, Dél-Olaszországban viszont lényegesen kevesebb könyvtár müködik és ezek is szegényes felszereltségüek. Nincs országos érvényü könyvtári törvény, a húsz régió önállóan szabályozza saját könyvtárai ügyét. A Torinói Királyi Könyvtár és a Savoyai királyi család rezidenciája teljes egészében az UNESCO világörökség részét képezi, és 1997 óta a város egyik legfontosabb intézménye. Az Andrea della Corte Zenei Könyvtár alapítását és dokumentumait tekintve az első és legjelentősebb olasz városi zenei könyvtár. A két könyvtár részletes bemutatása reprezentálja a muzeális megőrző helyek és az innovatív könyvtári szolgáltatások példáját.

\section{Történeti áttekintés}

Itália hosszú évszázadokon át vezető szerepet töltött be a könyv és a könyvtárak történetében, gazdag kultúrájával és egyedülálló könyvgyűjteményeivel. 1861-ben a széttagolt itáliai államok a Szárd Királyság vezetésével egységes Olaszországot hoztak létre. Az egyesítésig fennálló gazdasági, kulturális és társadalmi különbségek hatásai máig érezhetők. Az ország északi és déli részének fejlettsége között mély szakadék húzódik, mely kihat a könyvtárügyre is. Észak-Olaszország könyvtári ellátottsága gazdagnak mondható, itt található az ország könyvtárainak több mint a fele, DélOlaszországban kevesebb a könyvtár, és mind állományukat, mind felszereltségüket nézve, elmaradottabbak, szegényesebbek az északiakhoz képest. A dél-olaszországi könyvtárak állományának nagy része nem éri el még az ötezer kötetet sem. Olaszországban nincs országos érvényü törvény, a húsz régió önállóan szabályozza saját könyvtárai ügyét. Délen a gazdasági nehézségek miatt hiányoznak az eszközök a fejlesztésekhez, és az állam sem nyújt segítséget a könyvtárak ügyében. A könyvtárak technológiai felszereltsége elmaradottabb a közép-európai könyvtári színvonalhoz képest is. Észak-Olaszország könyvtárai jobb körülmények között müködnek, de csak a 2000-es évek táján indultak el az angolszász „public library” modell irányába, a modern könyvtárak útján. ${ }^{1}$ Az olasz könyvtárügy ellentmondásairól Giulia 


\section{KöMÜVes RenÁtA}

Barone és Armando Petrucci írtak 1976-ban megjelent Primo: non leggere! (Elöször: nem olvasni!) címü könyvükben. A szerzők úgy vélték, Olaszország nem fordít kellő figyelmet a könyvtáraira, nem vállal felelősséget a könyvtárak ügyével, nem törődik a bibliográfiák hasznosításával, és nem teszi mindenki számára elérhetővé az olvasás lehetőségét. A legnagyobb ellentmondás abban rejlik, hogy az állam, bár az ország kulturális öröksége példátlan gazdagságú és a legnagyobb művészektől való, a könyvtári gyüjteményekre pusztán, mint gyüjtő és őrző helyekre tekint, ahelyett, hogy a gazdag örökség használatát támogatná.

\section{Könyvtártípusok Olaszországban}

Olaszországban körülbelül 13.000 könyvtár müködik. Alapfeladatuk, hogy a könyvekből, időszaki kiadványokból, kéziratokból és egyéb dokumentumokból álló, együttesen közel 40 millió egységnyi dokumentumot tartalmazó gyüjteményeiket rendszerezett és feldolgozott formában elérhetővé tegyék a felhasználók számára. ${ }^{1} \mathrm{~A}$ könyvtárak eredetük (történetük) és müködésük szerint is rendkívül különbözőek, nehezen tipizálhatók. Itáliában minden más országnál változatosabb képet mutatnak a könyvtárak szolgáltatási és tevékenységi körei. ${ }^{2}$

Az olasz könyvtári rendszer gerincét 46 állami fenntartású könyvtár adja. Ezeket a könyvtárakat állami szinten egységesen szabályozzák, figyelembe véve a nemzetközi elöírásokat is.

\section{Nemzeti elnevezésü könyvtárak}

Olaszországban nincsenek meg az egyértelmüen elhatárolható könyvtártípusok. A „biblioteche statali” (állami könyvtárak) fenntartója és irányítója a kulturális tárca. Az állami fenntartású könyvtárak legfontosabb csoportját a „nemzeti” névvel ellátott könyvtárak alkotják: a két központi nemzeti könyvtáron kívül még nyolc könyvtár viseli ezt a nevet. Ezek az intézmények egyrészt a hajdani városállamok régi alapítású, az olasz írásos, kulturális örökség felbecsülhetetlen értékeit őrző könyvtárak, mint például Velencében a Szent Márkról elnevezett Biblioteca Marciana ${ }^{3}$, Rómában az Angelo Rocca püspök nevéhez füződő 1604-ben alapított (Európa legrégebbi nyilvános könyvtáraként számon tartott) Biblioteca Angelica4, vagy a Girolamo Casanate kardinális által, 1701-ben megnyitott 25 ezer kötetes magángyüjtemény (ma Biblioteca Casanatense $\left.{ }^{5}\right){ }^{6}$ Központi nemzeti könyvtár elnevezéssel emelik ki a Firenzei Nemzeti Könyvtár (Biblioteca Nazionale Centrale di Firenze - $\mathrm{BNCF}^{7}$ ) és a Római Központi Nemzeti Könyvtár (Biblioteca Nazionale Centrale di Roma - BNCR ${ }^{8}$ ) szerepét. ${ }^{9}$ 1861-ben az északi és déli tartományok egyesítésekor még Firenze a föváros Róma bizonytalan politikai helyzete miatt. A Firenzei Központi Nemzeti Könyvtárat két régi gyüjtemény, a Biblioteca Magliabechiana és a Biblioteca Palatina egyesítéséből hozták létre, és 1870-ben kötelespéldány-jogot is kapott. Miután 1876-ban a főváros Róma 
lett és ott is alapítottak egy nemzeti könyvtárat, de a firenzei könyvtár is megtartotta jogállását. Firenzében szerkesztik a nemzeti bibliográfiát (1958-tól), működtetik az Országos Könyvtárellátót (Servizio Bibliotecario Nazionale $-\mathrm{SBN}^{10}$ ), és feladatuk a könyvtárgépesítési fejlesztések összehangolása. A Római Központi Nemzeti Könyvtár a kéziratos művek kutatásának központja. 1991-től folyik a XVI. századi kiadványok rekatalogizálása. A római nemzeti könyvtár méltó elhelyezése sokáig megoldatlan volt, a múlt század hetvenes éveiben jutott funkciójának megfelelö épülethez. ${ }^{11}$ A további hat, nemzeti jelzővel ellátott könyvtár:

1. Biblioteca Nazionale Marciana, Velence (1468-)

2. Biblioteca Nazionale Universitaria di Torino, Torinó (1720-)

3. Biblioteca Nazionale Braidense, Milánó (1770-)

4. Biblioteca Nazionale di Napoli, Nápoly (1784-)

5. Biblioteca Nazionale Sagarriga Visconti Volpi, Bari (alapítva 1865, 1958 óta nemzeti könyvtár)

6. Biblioteca Nazionale Vittorio Emanuele III di Napoli, Nápoly (1804-)

Az olasz könyvtári rendszerben jelentős szerepet tölt be az Országos Könyvtárellátó, az Olasz Digitális Könyvtár (Biblioteca Digitale Italiana ${ }^{12}$ ) és a Kulturális Portál (Internet Culturale $\left.{ }^{13}\right)$.

\section{Közkönyvtárak}

A kulturális minisztérium által fenntartott állami könyvtárak másik csoportja a városok lakóinak igényeit elégíti ki. Ez a könyvtártípus az 1970-es évekig szinte teljesen hiányzott az ország könyvtári hálózatából. A hetvenes években a települések a tartományi rendelkezések alapján kezdték a könyvtári szolgáltatást megteremteni a lakosság számára. Ekkor kezdődött a közkönyvtárak elterjedése, de fejlődésük régiónként (tartományonként) eltérő ütemü és színvonalú volt. Olaszországban a közkönyvtárak a városokhoz és a községekhez tartoznak. ${ }^{14}$ Jól müködő könyvtárra példa a trieszti Biblioteca Statale ${ }^{15}$, mely gyermek és ifjúsági részleggel, bibliobusszal, kórházi és börtönkönyvtári kölcsönző állomásokkal várja látogatóit, vagy a Rómában 1862-ben alapított, 120 ezer kötettel rendelkező Biblioteca Statale Antonio Baldini ${ }^{16}$. A régiók többségében is müködnek állami fenntartású közkönyvtárak, meg a régiók által fenntartottak is. A közkönyvtári rendszert még komplikáltabbá teszi, hogy az egyetemi könyvtárak nagy részének is az állam a fenntartója.

\section{Városi könyvtárak}

Az állam ezeken kívül még 38 nyilvános közkönyvtárat müködtet. Föként városi könyvtárakat „biblioteca civica” elnevezéssel, melyek feladata a helyi lakosság könyvtári ellátása, és csak fenntartójukban különböznek a városok (tartományok, régiók) által müködtetett állami könyvtáraktól. Nagy részük régi városi gyüjteményből vagy magánkönyvtárból alakult ki, ezért gyüjteményükben számos különlegesség, speciális 


\section{KöMÜVes RenÁtA}

tartalmú dokumentum található. Észak és Közép-Olaszország kis- és középvárosaiban működő könyvtárak egy része már modernizálódott, a városi könyvtárak is új, vagy legalábbis átépített épületben müködnek. A nagyvárosokban lévő könyvtárak helyzete viszont rosszabb, mert csak kevés helyen valósult meg az intézmények korszerüsítése. Például Torinóban 17 fiókkönyvtár müködik hálózati rendszerben, de nincs a város nagyságának megfelelő központi könyvtár. ${ }^{17}$

\section{Olasz könyvtártudományi kézikönyvek}

Az Editrice Bibliografica nevü olasz könyvkiadó I manuali della biblioteca (Könyvtári kézikönyvek) című sorozatának kötetei a könyvtáros szakma alapműveinek számítanak Olaszországban. A magyarországi Könyvtárosok kézikönyvéhez hasonlóan összefoglalják az egyes szakterületek legfontosabb tudnivalóit (például a könyvnyomtatás és tipográfia története, a katalógusok, a katalógusszerkesztés szabályai, információszervezés, információkeresés, adatbázisok használata, könyvtártípusok, a könyvtárak jogi szabályozása, a könyvtárosok szükséges kompetenciái, teljesítményértékelés, minőségmenedzsment stb.). ${ }^{18}$

2007-ben Milánóban a sorozat részeként jelent meg egy csaknem ezer oldalas összefoglaló kézikönyv, a Biblioteconomia: guida classificata (Könyvtártudomány: minősített útmutató ${ }^{19}$ címmel. Elsősorban az egyetemi hallgatóknak és a gyakorló szakembereknek készült. Példaértékü, ahogy a könyv országos szakmai összefogás eredményeként megszületett, mely szerkesztési koncepciójában, tartalmi felépítésében is újszerü volt. A munkát szakenciklopédiának is nevezhetnénk, mert tematikus elrendezésben szintetizálja a könyvtártudomány egyetemes és olasz ismeretanyagát. Definíciókat ad, alapismereteket közöl, történeti áttekintést is ad és forrásokkal segíti a tárgyalt témakörök további tanulmányozását. Szerkesztési érdekesség, hogy a Biblioteconomia merész ötlettel a Dewey tizedes osztályozás legutóbbi, 22. kiadása szerint rendezi anyagát: a legfelsőbb hierarchiaszintek háromjegyü jelzetei utalnak a tárgyalt témakörökre. Például a 01 jelzetnél a Bibliográfia és a nemzeti könyvtárak fejezet, a 02 osztályban a Könyvtártudomány ismeretei találhatók stb. A használata azonban kicsit nehézkes azok számára, akik nem jártasak az információkereső nyelvek világában. ${ }^{20}$

A sorozat részeként jelent meg Antony Charles Foskett híres kézikönyvének, a The subject approach to information-nek olasz fordítása Il Soggetto (A tárgy) címen, mely a legteljesebb összefoglalása az információkeresésnek és az adatbázisokról való ismereteknek ${ }^{21}$.

Az olasz nemzeti bibliográfia (Bibliografia nazionale italiana - BNI) 1958 óta regisztrálja az Itáliában megjelent és a Firenzei Központi Nemzeti Könyvtárba (Biblioteca Nazionale Centrale di Firenze - BNCF) kötelespéldányként beszolgáltatott könyvek bibliográfiai leírását. Az 1886 és 1957 közötti időszakból azokat a kiadványokat regisztrálták, melyek nyomtatási joggal rendelkeztek. A nemzeti bibliográfia dokumentumtípusok szerinti sorozatait 2012 után már nem nyomtatásban, hanem digitálisan tették elérhetővé, 
előfizetéshez kötve. 2016-tól a Firenzei Nemzeti Könyvtár honlapján, szabadon hozzáférhető tételek, melyek a Dewey-féle Tizedes Osztályozás alapján kereshetők és PDF-formátumban letölthetők. A monográfiákról havonta, az időszaki kiadványokról és a zenei müvekről félévenként, a doktori disszertációkról évente jelenik meg a bibliográfia. Az 1958-ig visszamenő retrokonverzión folyamatosan dolgoznak. A gyüjtemény jelenleg 650.000 dokumentumból áll, és évente mintegy 20.000 dokumentummal gyarapszik. ${ }^{22}$

\section{A „Közkönyvtárak 2020” projekt}

A „Közkönyvtárak 2020” elnevezésű programnak (Public Libraries 2020 - erős európai közösség építése) fö célja, hogy felhívja a társadalom figyelmét a közkönyvtárak fontosságára, melyek mindinkább a helyi közösségi élet modern csomópontjaivá, központi tereivé válnak. Szerepük az utóbbi években jelentősen megnövekedett a közösségépítésben: speciális programjaikkal támogatják a helyi közösségek müködését, és információs bázist adnak az életen át tartó tanulás folyamatához is. ${ }^{23}$

A projekt keretében összehasonlíthatóvá váltak az Európai Unió tagállamainak könyvtári és képzettségi mutatói a Digitális Gazdasági és Társadalmi Index (Digital Economy and Society Index - DESI) és az IFLA (International Federation of Library Associations and Institutions - IFLA ${ }^{24}$ ) statisztikai adatai alapján. ${ }^{25}$ A 2017 -es adatok szerint Olaszország népessége 60,7 millió fö, ezért egy könyvtárra 10046 lakos ellátása hárul. Az országban 6042 közkönyvtár müködik (1. ábra), melyeket évente 7,3 millió 18 év fölötti olvasó használ. A használók 43\%-a vesz részt a könyvtárak által szervezett különféle képzési programokon. A közkönyvtárak 65\%-a rendelkezik internet-hozzáféréssel, 45\%-uk biztosítja az e-könyvek kölcsönzését is, 24\%-uk szervez rendszeresen tanfolyamokat a helyi lakosság digitális és információs müveltségének fejlesztésére. 800.000 felnőtt olvasó használ a könyvtárban számítógépet.

Ha a 9,9 millió fös magyarországi lakosságot nézzük, egy közkönyvtárra 2952 lakos jut, és 3384 közkönyvtár (2. ábra) működik Magyarországon, melyek 1512533 felnőtt használóval rendelkeznek. Nálunk 45 ezer használó vett részt 2016-ban valamilyen digitális készségeket fejlesztő könyvtári képzésen. A közkönyvtárak 88\%-a rendelkezik internet-hozzáféréssel és 2,4 millió ember használja az internetet helyben. A statisztikát megelőző évben a könyvtárakat összesen 34130797 alkalommal látogatták és összesen mintegy 22 millió könyvet kölcsönöztek ki. ${ }^{26}$

Olaszország a 25. helyen áll a Digitális Gazdaság és Szociális Index rangsorában. Az olasz felnőttek 8\%-a vesz részt az egész életen át tartó tanulásban. A munkaadók 29,5\%-a állandóan azért küzd, hogy megfelelő szaktudással, szakmai készségekkel rendelkező munkavállalót találjon. A felnőttek 28\%-ának alacsony szintű az írás-olvasási képessége, 32\%-uknak még a matematikai készsége is problémás. Sokan a közkönyvtárban kapcsolódnak először az internetre, és a rendszeres internet-használók aránya is viszonylag alacsony. ${ }^{27}$ 


\section{KöMÜVes RenÁtA}

Magyarország a 20. helyen áll a Digitális Gazdaság és Szociális Index rangsorban. A felnőttek 6\%-a vesz részt az élethosszig tartó tanulást segítő valamilyen oktatási formán, a munkaadók 56,8\%-a küzd azzal, hogy megfelelő szaktudású munkavállalót találjon. Mi ugyanakkor jobb helyet foglalunk el az internetes jelenlét, internet-használat rangsorában, mint az olaszok. ${ }^{28}$

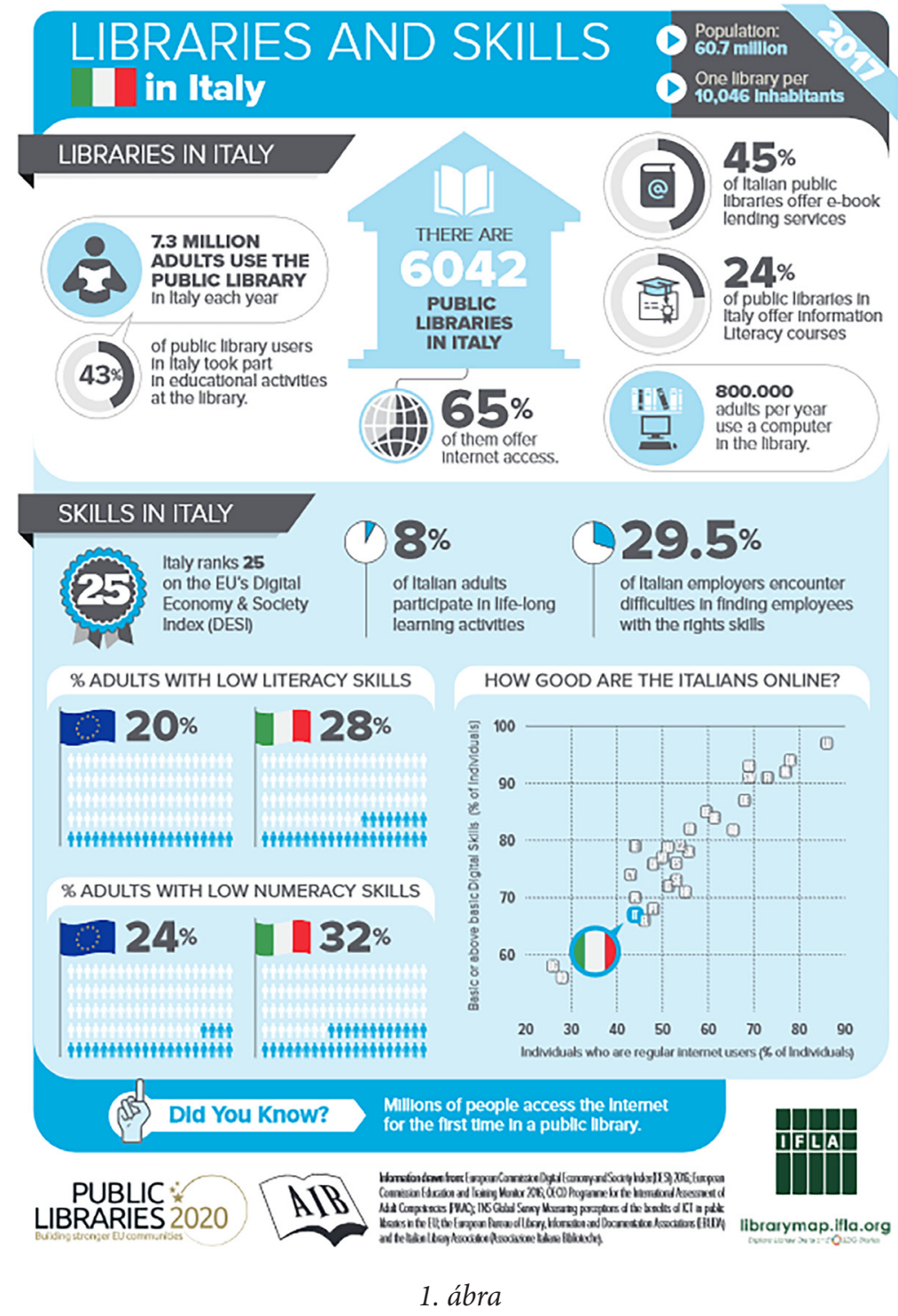

Olaszország 2017-es könyvtári statisztikája

Forrás: https://publiclibraries2030.eu/wp-content/uploads/2019/02/Italy-2017.pdf 


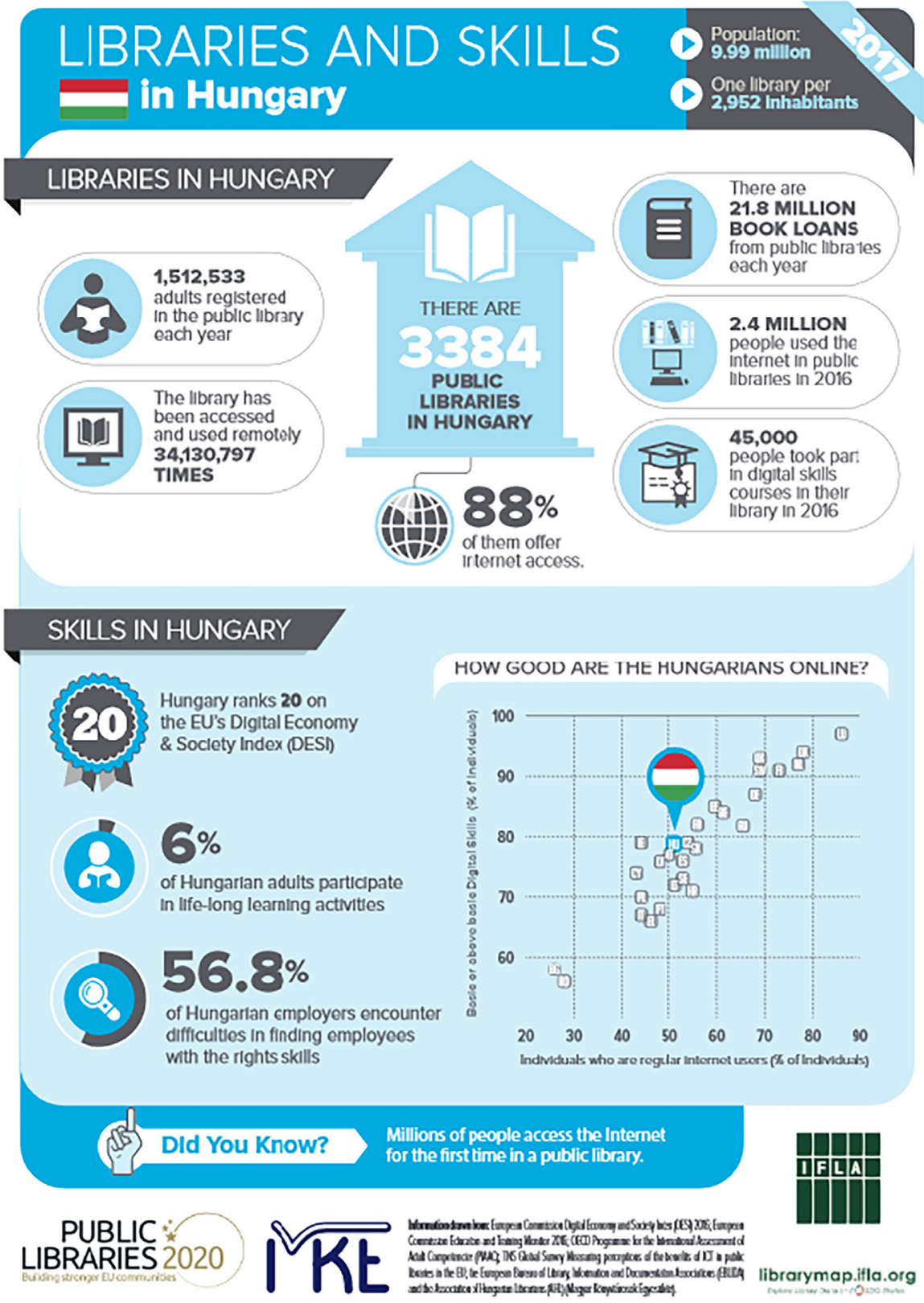

\section{2. ábra}

Magyarország 2017-es könyvtári statisztikája

Forrás: https://publiclibraries2030.eu/wp-content/uploads/2019/02/Hungary-2017.pdf 
KőMÜVES RENÁTA

\section{A BiblioPride - Nemzeti Könyvtári Nap Olaszországban}

2012. október 8-a és október 14-e között rendezték meg először a BiblioPride programot (Nemzeti Könyvtári Nap), mellyel a könyvtárak fontosságára kívánták felhívni a figyelmet. Az évente ismétlődő programsorozat szervezője az Olasz Könyvtáregyesület (Associazione Italiana Biblioteche - AIB). Az Egyesületet 1930-ban alapították, és jelenleg is a legrégebbi és legnagyobb szakmai szervezet könyvtári területen Olaszországban. 2012-ben Nápoly adott otthont az országos összefogásra épülő programnak. A BiblioPride céljai között szerepel, hogy rámutasson a könyvtárak szerepére az ország kulturális, gazdasági és társadalmi életében. A program előzménye a 2011. október 22-én indított Könyvtárak Éjszakája címü esemény volt. A Könyvtári Nap szervezését minden évben más város vállalja: 2013-ban Firenze, 2014-ben Puglia, 2015-ben Milánó, 2016-ban Nápoly, 2017-ben Pistoia, 2018-ban pedig Róma volt a BiblioPride városa. Minden évben egyre több könyvtár csatlakozik a mozgalomhoz, és évről évre egyre bővülő programkínálattal (koncertekkel, flashmobokkal, író-olvasó találkozókkal) várják a lakosságot. ${ }^{29}$

\section{Piemonte régió és Torinó történelmi múltja}

Észak-Itália többi részéhez hasonlóan Torinó is először a Római Birodalom, majd a gótok, a longobárdok és a frankok uralma alatt állt. 1574-től a Savoyai Hercegség központja volt, rövid ideig a városban ülésezett az egységes Olaszország parlamentje. A Savoyaiak 1720-ban elfoglalták Szardíniát, de Napóleon megszüntette a befolyásukat és 1798-ban elfoglalta Torinót is. A város porosz és osztrák megszállásának I. Viktor Emánuel vetett véget azzal, hogy életre keltette a Savoyai-házat, majd 1814-ben uralma alá helyezte Torinót. Három évvel később a föváros székhelye átkerült Firenzébe. Torinó pedig elvesztette ugyan politikai jelentőségét, de mint ipari nagyváros sikeresen fejlődött és egyúttal a szakszervezeti mozgalom bölcsőjévé vált.

Torinó Olaszország negyedik legnépesebb városa, Piemonte régió székhelye, fontos üzleti, kulturális, és oktatási központ. A Pó partjánál fekvő Torinót Európa barokk fóvárosának is nevezik. Lakóinak száma az agglomerációval együtt eléri az 1,7 millió föt. A régió nagyban különbözik Olaszország többi részétől: északi részei Svájcot idézik, míg tágas tereivel, árkádjaival, és élénk kávéházi életével inkább francia, mint olasz hatást mutat. ${ }^{30}$

\section{Torinó könyvtári hálózata}

Olaszország könyvtárainak impozáns épületei és a könyvtáraknak a tudományos közéletben betöltött szerepe arra utal, hogy a múlt századokban a könyvtárakat elsősorban a művelt elit közönség számára tartották fenn. ${ }^{31}$ 


\section{Nemzeti Egyetemi Könyvtár}

Torinó egyik fö könyvtára a Nemzeti Egyetemi Könyvtár (Biblioteca nazionale universitaria di Torinó), melyet 1720-ban II. Viktor Amadeus alapított Királyi Egyetemi Könyvtárként, egyesítve a Torinói Egyetem (Università degli Studi di Torino) könyvtárának és a Savoyai-ház hercegeinek könyvgyüjteményeit. 1872-ben, Olaszország egyesülése után nevezték át Nemzeti Könyvtárrá. 1904-ben tüz pusztította el a könyvek és kéziratok ezreit. Eminia Cuadana restaurátor nevéhez füződik a károk helyreállítása. A könyvtárat 1942 decemberében bombatalálat érte. Napjainkban a könyvtárban több mint hétszázezer könyv, ezernél több folyóirat és 1600 ősnyomtatvány is található. ${ }^{32}$

\section{Bibliobusz}

Torinóban is elérhető a bibliobusz kínálta könyvtári szolgáltatás. A járművet 2018 októberében indították el azzal a céllal, hogy a városi könyvtárak által ellátatlan területeken is biztosítani tudják a könyvekhez való hozzáférést. A bibliobusz wifivel rendelkezik, és alkalmanként ezer kötetet tesz hozzáférhetővé, digitális szolgáltatásokat kínál, valamint megjelenik rendezvényeken is. ${ }^{33}$

\section{Torinói Királyi Könyvtár}

\section{A könyvtár története}

A Torinói Királyi Könyvtár (Biblioteca Reale di Torino) a Torinói Királyi Palota (Palazzo Reale di Torino) földszintjén található. A palota a Savoyai királyi család rezidenciájaként az UNESCO világörökség részét képezi, és a város egyik legfontosabb intézménye.

1831-ben, trónra lépésekor I. Károly Albert (Carlo Alberto di Savoia I. 17981849), Szardínia királya a nemzet kulturális felemelése érdekében úgy döntött, hogy kibővíti udvari könyvtárát ${ }^{34}$, ezért nagyszabású vásárlásokat indított Európa-szerte. A gyüjteményt kiegészítette anyai nagyanyja, Joséphine de Lorraine könyvtárával, aki II. Victor Amadeus feleségeként, müvelt asszony volt és nyitott a XVIII. század eszméi iránt. ${ }^{35} 1839$-ben a király megvásárolta Giovanni Volpato gyüjtőtől néhány nagy müvész (Michelangelo, Raffaello, Rembrandt és Leonardo da Vinci) műveit. ${ }^{36}$ A gyüjteményben található Leonardo híres, vörös krétával rajzolt önarcképe és a Sziklás Madonnáról készült tanulmánya, Verrocchio Krisztus megkeresztelkedéséről írt tanulmánya pedig a XIX. század végén került a könyvtár tulajdonába. A gyüjtemény elhelyezésére Carlo Alberto a királyi palota keleti szárnyát választotta, alatta a királyi fegyvertár volt. A korábban raktárként használt helyiséget Pelagio Palagi építész alakította át könyvtárrá. Neoklasszikus stílusban tervezte, fa padlózattal, a mennyezetén freskókkal. Két szintjén diófa könyvespolcokat helyezett el, a galériát kovácsoltvas korláttal vették körül. A könyvtárat a király parancsára megnyitották az állami tisztviselők és a tudósok előtt. A könyvállomány gyors gyarapodása miatt hamarosan szüknek bizonyult a tér, ezért a könyvtár 1842-ben a királyi palota ke- 


\section{KÖMÜVES RENÁtA}

leti szárnyának földszintjére, egy nagyobb térbe költözött. Amikor a II. világháború után a Savoyai-ház vagyona az állam tulajdonába került, a Királyi Könyvtár nyilvános könyvtár lett és a Kulturális Örökségvédelmi és Művelődésügyi Minisztérium (Ministeri per Beni e Le Attività Culturali - MiBAC) irányítása alá került. A Királyi Könyvtár gyüjteménye különösen gazdag történelmi, földrajzi, művészeti és közgazdaságtani munkákban, valamint természettudományi művekben. Az állomány körülbelül 200.000 kötetet, 4500 kéziratot, 3055 grafikai anyagot, 187 ősnyomtatványt, több mint ötezer XVI. századi könyvet, 1500 pergamenre írt művet, és ezernél több folyóiratot, továbbá fotóanyagot, térképeket, metszeteket tartalmaz. Kincseinek megfelelő és biztonságos kiállítására, a legmodernebb biztonsági technikák alkalmazásával 1998-ban földalatti kiállítótermet alakítottak ki. ${ }^{37}$ Gyönyörű kiállítóterme rendkívül népszerű a turisták körében. ${ }^{38}$

\section{A könyvtár szolgáltatásai}

A könyvtár olvasóterme hétfőtől szombatig szabadon látogatható. A Királyi Múzeum nem rendelkezik wifi-használattal, de a Királyi Könyvtár viszont igen: ingyenes internet-használatot biztosítanak a könyvtárba látogatók, illetve az olvasótermet használó kutatók részére.

2015 januárjában átfogó kiállításon mutatták be Leonardo da Vinci önarcképét és felbecsülhetetlen értékü müveit. 2017-ben egy újabb Leonardo-kiállításnak adott otthont a palota. A könyvtárat is és a Leonardo-hagyatékot is kiscsoportos, vezetett bemutatás során lehetett megtekinteni. ${ }^{39}$

Mivel 2019-ben Leonardo da Vinci halálának 500. évfordulóját ünnepli Olaszország, a torinói királyi palotában április 15-én nyílt meg a Leonardo da Vinci - A jövőt megrajzolni című kiállítás, valamint ezzel egyidőben a velencei képtárában a Leonardo da Vinci - Az ember a világ modellje címü kiállítás. Az évforduló alkalmából a híres önarckép mellett bemutatták a Carlo Alberto által vásárolt alkotásokat is. Az évfordulóra az olasz posta négy bélyeget bocsátott ki, az olasz jegybank pedig kéteurós pénzérméket hozott forgalomba a Hölgy hermelinnel címü festmény részletével. ${ }^{40}$

Az évfordulóhoz kapcsolódva Magyarországon az év folyamán bemutatják „A művészet templomai: Leonardo 500" című olasz ismeretterjesztő filmet.

\section{Villa Tesoriera, az Andrea Della Corte Városi Zenei Könyvtár}

\section{Az épület története}

A Villa La Tesoriera XVIII. századi barokk palota Torinóban a Corso Francia 186os szám alatt található. A Corso Francia Torinó egyik fóútvonala, mely csaknem 12 km hosszúságával Európa leghosszabb egyenes útja (Torinó, Collegno és Rivoli városokon halad keresztül). A villa föépülete 1713 és 1715 között épült Aymo Ferrero Cocconato államtanácsos részére. Első emeletének díszítése Jacopo Maggi díszletfestő, 
a torinói Teatro Regio munkatársa nevéhez füződik. Felavatására 1715-ben került sor, melyen részt vett II. Victor Amadeus király és udvartartása. Ferrero halála (1723) után a palota egyik kézből a másikba került, majd hanyatlásnak indult. Amikor a franciák megszállták a régiót, a katonák laktanyaként használták. 1869-ben az épületet Ferdinando Arborio Gattinara di Breme szenátor vette meg. A szenátor szenvedélyes bibliofil és műgyűjtő volt, újabb szárnnyal bővítette az épületet és francia és holland stílusú parkot alakíttatott ki. Ebben az időben a Tesoriera palota további értékes gyüjteményekkel gyarapodott, többek között egy természettudományi és botanikai könyvgyüjteménnyel. Sartirana hercegének 1869-ben bekövetkezett halálával újabb tulajdonjogi változások következtek. 1934-ben az épületet Umberto herceg örökölte és tovább bővítette a nyugati szárnnyal. Az épület mai formáját 1941-ben nyerte el. 1943 és 1944 között a német megszállás alatt eltűnt az értékes könyvtárés bútorgyüjtemény. 1962-ben a villát a jezsuitáknak adták el oktatási célokra, majd 1971-ben Torinó város megvásárolta a birtokot és a villát, közösségi térként való használatra szánta. Az átfogó helyreállítási munkákat 1979-ben Nicola di Aramengo irányította, majd 2009-ben ismételt felújításokra volt szükség. A helyreállított palotát 2012-ben nyitották meg a közönség előtt. Akkor került az épületbe Andrea della Corte zenei könyvgyüjteménye is. ${ }^{41}$

\section{Az Andrea Della Corte Városi Zenei Könyvtár története}

A könyvtárat 1946-ban alapították a városi könyvtár és Torinó történelmi gyüjteményeinek önálló részlegeként. Giacomo Sacerdote ügyvéd hagyatékából XVI. és XVIII. századi opera-szövegkönyveket kaptak, valamint a könyvkiadók is ajánlottak példányokat az általuk kiadott zenei alkotásokból. A könyvtár első székhelye a zenei konzervatórium épületében volt a Via Rossini 8. szám alatt. 1956-ra a gyüjtemény kinőtte a helyét, ezért átkerült a Via Roma 53-as szám alatti helyiségekbe, ahol hanglemeztárat hoztak létre, lehetőséget kínálva a hangzó dokumentumok lejátszására. 1968-ban Andrea Della Corte kritikus és zenetudós halála után a család a hangarchívumát és majdnem 15.000 kötetes könyvtárát a városnak adományozta. A hagyaték a zenei könyvtár állományába került, és a könyvtár ekkor vette fel a zenetudós nevét. 1981-ben újabb költözésre szánták rá magukat, és a könyvtár a Villa Tesorierában talált megfelelő helyet. 1992-ben befogadta a táncmüvészeti kutatóközpontot, és azóta a könyvtár jelentős táncművészeti dokumentációs anyagot is szolgáltat. Később az épületen további felújítási munkákat végeztek, hogy a bővülő könyvtári funkciókhoz jobban igazodó tereket tudjanak kialakítani. Az átalakított könyvtár 2012 júniusában nyílt meg a közönség számára. A felújításnak köszönhetően kibővültek a használható könyvtári terek, ${ }^{42}$ és az épület a parkkal együtt a város látványossága és a látogatók kedvelt pihenőhelye lett. ${ }^{43}$ 


\section{A könyvtár szolgáltatásai}

A könyvtárban tett látogatásomkor megcsodálhattam a parkot és a zenei könyvtár működését a barokk villában. Egy kedves kolléganő vezetett körbe, akitől sokat megtudtam a könyvtár szolgáltatásairól és saját szememmel is tapasztalhattam, milyen sokan használják. Mindkét - 25 férőhelyes - olvasóterme tele volt látogatókkal, akik a gyönyörü freskókkal díszített termekben dolgoztak, tanultak vagy kutattak. A könyvtár feladata az információszolgáltatás mellett a zenei kultúra terjesztése, az olasz és külföldi zenészek, kutatók, és a zene iránt érdeklődők teljes körű kiszolgálása, ellátása. Helyiségei kiválóan megfelelnek a különféle zenei, kulturális és oktatási rendezvények lebonyolítására. A gyüjtemény helyben használata, a kölcsönzés, valamint a zeneteremben rendelkezésre álló eszközök igénybevétele és a kulturális, illetve zenei programokon való részvétel ingyenes. Kölcsönözhetők a zenei- és táncművészeti tanulmányok, zenei CD-k, videofelvételek, DVD-k és Blu-ray lemezek. Az alsó szinten található a regisztrációs, ill. ellenőrző pult, az olvasótermek és a folyóirat-olvasó, ahol 226 zenei- és táncművészeti periodika használható. A folyóirat-olvasóval szemben önkiszolgáló másológép és szkenner kapott helyet, valamint segédeszközök a látássérült látogatók számára. Mellette található a Zeneterem, ${ }^{44}$ mely két digitális zongorával (Kawai CA63, Yamaha P-85), egy Fender American Standard Stratocaster elektromos gitárral, egy MIDI billentyüzettel és két komponálásra alkalmas számítógéppel (Digital AudioWorkstation) van felszerelve, gyakorlatilag virtuális stúdióként működik. A rendelkezésre álló zenei szoftverek használatára heti rendszerességgel képzéseket is szerveznek.

A magyarországi könyvtárak zenei gyüjteményei nem rendelkeznek ilyen színvonalas technikai eszközparkkal. A Zeneakadémia könyvtárában gyakorlás céljából van egy digitális pianínó. A szegedi Somogyi-könyvtárban is található egy, itt rendezvényekhez használják. A szolnoki Verseghy Ferenc Könyvtárban van hangszer, de nincs hozzá program, szolgáltatás, főleg a kórusuk veszi igénybe. A pécsi Csorba Győző könyvtárban is található egy KAWAI KDP80 típusú digitális zongora, melyet fejhallgató segítségével lehet használni a kottákkal való ismerkedés céljára, valamint a könyvtári rendezvényeken használják. 2019 januárjában a kecskeméti Katona József Könyvtárban nyílt Kreatív stúdió, amelynek része egy hordozható Orlastagestudio CDP 101-es digitális zongora, melyen hangfelvétel készíthető. Kreatív stúdió szolgáltatás is indult, hogy a multimédiás tartalmak (film, zene, müsor) készítésének technikáját, módszereit megismertessék a könyvtárhasználókkal. ${ }^{45}$

A villa emeletén található koncerttermet zenei előadások, zenei képzések, könyvbemutatók és konferenciák megrendezésére használják. Látogatásom napján részese lehettem a minden csütörtökön megrendezésre kerülő koncertek egyikének. A könyvtár rendszeresen helyet ad különböző előadásoknak és kiállításoknak is, melyekről szórólapokon és honlapjukon adnak tájékoztatást. Oldaluk folyamatosan frissül és zenei, színházi eseményeket ajánló írásokat találunk rajta. 
Az intézmény akadálymentes, a liftnek köszönhetően mozgássérültek számára is hozzáférhető. A húsz hallgatóállomással felszerelt multimédia teremben audiovizuális anyagokat hallgathatnak, illetve nézhetnek a látogatók. Külön helyiségbe kerülnek a legújabb beszerzések. A könyvtár részt vesz helyi és országos szinten is a könyvtárközi kölcsönzésben. Az érdeklődők vezetett látogatásokon járhatják be az épületet. Az Andrea della Corte Zenei Könyvtár alapítását és dokumentumai gazdagságát tekintve, az első és legjelentősebb olasz városi zenei könyvtár. ${ }^{46}$ Jellemző adatai: 82380 zenei és táncművészeti könyv, 3650 darab szövegkönyv, 30749 audiovizuális dokumentum, 193 mikrofilm tartozik a gyüjteményébe. ${ }^{47}$

Olaszországban könyvtárak százai örzik a múlt írásos emlékeit. Az olasz könyvtári viszonyok viszonylagos elmaradottsága ellenére nagy élmény volt látni az UNESCO világörökségi listáján szereplő Torinói Királyi Könyvtárat, és a nagy múltú barokk villában a Villa Tesorierát, mely otthonául szolgál a legjelentősebb olasz zenei gyüjteménynek.

Olaszország népessége hatszorosa hazánk lakosságáénak, könyvtárainak száma pedig a duplája, mégis kétszer annyi olvasóval, könyvtárlátogatóval rendelkeznek, mint a magyar könyvtárak. Magam is ezt tapasztaltam a zenei könyvtárban tett látogatáskor, mert a könyvtár olvasótermei tele voltak használókkal.

\section{Irodalom és jegyzetek}

1. HASENAU, Christina: Sok fény és sok árnyék: az olasz könyvtárak (Töm.: Katsányi Sándor). = Könyvtári Figyelö, 20. 56. évf. 3. sz. 2010. 481. p.

2. ALENÉ GÁL Margit - OLAJOS Laura: Az olasz könyvtári rendszerről. Forrás: http:// tudasalapitvany.hu/tudas-library/olasz-konyvtar.pdf [2019. április 24.] 1-4. p.

3. Biblioteca Marciana Velencében. Forrás: https://marciana.venezia.sbn.it [2019. május 22.]

4. Biblioteca Angelica Rómában. Forrás: http://www.bibliotecaangelica.beniculturali.it/index.php?en/1/home [2019. május 22.]

5. Biblioteca Casanatense Rómában. Forrás: http://www.casanatense.it/it [2019. május 22.]

6. HASENAU, C.: i. m. 482. p.

7. Biblioteca Nazionale Centrale di Firenze. Forrás: https://www.bncf.firenze.sbn.it [2019. május 22.]

8. Biblioteca Nazionale Centrale di Roma. Forrás: http://www.bncrm.beniculturali.it [2019. május 22.]

9. ALENÉ GÁL Margit - OLAJOS Laura: i. m. 4. p.

10. Országos Könyvtárellátó. Forrás: https://opac.sbn.it/opacsbn/opac/iccu/free.jsp [2019. május 22.]

11. HASENAU, C.: i. m. 482. p.

12. Biblioteca Digitale Italiana. Forrás: http://www.internetculturale.it/it/1038/biblioteca-digitaleitaliana [2019. május 22.]

13. Internet Culturale. Forrás: http://www.internetculturale.it [2019. május 22.] 


\section{KöMÜVes RenÁtA}

14. ALENÉ GÁL Margit - OLAJOS Laura: Az olasz könyvtári rendszerről. Forrás: http:// tudasalapitvany.hu/tudas-library/olasz-konyvtar.pdf [2019. május 14.] 4-5. p.

15. Biblioteca Statale Stelio Crise di Trieste. Forrás: http://www.bsts.librari.beniculturali.it [2019. május 22.]

16. Biblioteca Statale Antonio Baldini. Forrás: http://www.bibliotecabaldini.beniculturali.it [2019. május 22.]

17. HASENAU, C.: i. m. 482-484. p.

18. I manuali della biblioteca sorozat részei. Forrás: https://www.editricebibliografica.it/libricollana-i-manuali-della-biblioteca-26957.html [2019. július 10.]

19. CRUPI, Gianfranco - GUERRINI, Mauro (ed): Biblioteconomia. Guida classificata. Editrice Bibliografica, 2007.

20. DUDÁS Anikó: Olasz kézikönyv Dewey-nyomdokain = Könyvtári Figyelö, 18. (54.) évf. 4. sz. 2008. 677-682. p.

21. FOSKETT, Antony C.: Il Soggetto. Editrice Bibliografica, 2001.

22. A Firenzei Központi Nemzeti Könyvtár hivatalos oldala. Forrás: https://www.bncf.firenze. sbn.it/pagina.php?id=187\&rigamenu=Presentazione [2019. július 13.]

23. Reading \& Writing Foundation. Forrás: http://readingandwriting.eu/literacy-life [2019. május 14.]

24. IFLA. Forrás: https://www.ifla.org [2019. május 22.]

25. Public Libraries 2030. EU országok adatlapjai. Forrás: https://publiclibraries2030.eu/resources/eu-library-factsheets [2019. május 14.]

26. Public Libraries 2030. Magyarország statisztikája. Forrás: https://publiclibraries2030.eu/ wp-content/uploads/2019/02/Hungary-2017.pdf [2019. május 17.]

27. Public Libraries 2030. Olaszország statisztikája. Forrás: https://publiclibraries2030.eu/wpcontent/uploads/2019/02/Italy-2017.pdf [2019. május 14.]

28. Public Libraries 2030. Magyarország statisztikája. Forrás: https://publiclibraries2030.eu/ wp-content/uploads/2019/02/Hungary-2017.pdf [2019. május 17.]

29. Az Olasz Könyvtári Egyesület (AIB) hivatalos weboldala. Forrás: www.aib.it/attivitabibliopride2012 [2019. május 16.]

30. Olaszország. Budapest, Park Kiadó, 2005. (Vista könyvek) 231-234. p.

31. A New York Times weboldala. Forrás: https://www.nytimes.com/2017/06/13/travel/whatto-read-tour-of-italian-libraries.html?action=click\&module=RelatedCoverage\&pgtype $=$ Article\&region=Footer [2019. május 7.]

32. A Torinói Nemzeti Egyetemi Könyvtár hivatalos weboldala. Forrás: http://www.bnto.librari. beniculturali.it/index.php?it/146/storia [2019. május 07.]

33. Torinó városi könyvtárainak weboldala. Forrás: http://www.comune.torino.it/cultura/biblioteche/sedi_orari/bibliobus.shtml [2019. május 14.]

34. A Musei Reali Torino hivatalos weboldala. Forrás: https://www.museireali.beniculturali. it/biblioteca-reale [2019. május 09.]

35. The Royal Library in Turin. PDF-dokumentum. Forrás: http://www.bibliotecarealepiemonte. beniculturali.it/attachments/article/17/inglese.pdf [2019. május 9.]

36. A Musei Reali Torino hivatalos weboldala. Forrás: https://www.museireali.beniculturali. it/biblioteca-reale [2019. május 9.]

37. The Royal Library in Turin. PDF-dokumentum. i. m. 
38. Leonardo Kiállítás. Forrás: https://www.dw.com/en/leonardo-one-a-state-of-the-art-datacontrolled-vault-for-a-most-famous-selfie/a-18137874 [2019.május 21.]

39. A Turin Italy Guide weboldala. Forrás: http://www.turinitalyguide.com/leonardo-da-vinci [2019. július 12.]

40. Az 500 éves évforduló hivatalos weboldala. Forrás: http://www.celebrandoleonardo500.com [2019. július 12.].

41. A Villa Tesoriera angol nyelvü weboldala. Forrás: http://www.villacomposers.org/id2-020000.php [2019. április 26.]

42. A Villa Tesoriera hivatalos weboldala. Forrás: https://bibliotecadellacorte.com/info [2019. április 27.]

43. A Villa Tesoriera épülete. Forrás: https://www.piemonteitalia.eu/en/cultura/biblioteche/ biblioteca-civica-musicale-andrea-della-corte [2019. május 21.]

44. A Biblioteca Musicale Andrea Della Corte zeneterme. Forrás: https://bibliotecadellacorte. com/sala-musica [2019. május 16.]

45. Információ a Zenei könyvtárosok levelezőlistájáról, Zsoldos Marianna, a Bródy Sándor Könyvtár Zenei és Idegen Nyelvi Gyüjtemény munkatársának közbenjárásával.

46. Forrás: Látogatás alkalmával az elhangzottak alapján készített saját jegyzet.

47. A Villa Tesoriera angol nyelvű weboldala. Forrás: http://www.villacomposers.org/id2-020000.php [2019. április 26.]

Kömüves Renáta az ELTE BTK informatikus könyvtáros mesterképzésen végzett 2016 nyarán. Barátné Hajdu Ágnes témavezetésével írta szakdolgozatát és diplomamunkáját, valamint készítette el OTDK dolgozatát két alkalommal. Az egyetem befejezése óta Sopronban dolgozik a Széchenyi István Városi Könyvtárban szakirodalmi tájékoztató könyvtárosként. ORCID ID: 0000-0003-3700-7612 